\title{
In vitro Evaluation of Botanicals, Bioagents and Antibacterial Chemicals against Rhizome Rot of Ginger Caused by Ralstonia solanacearum
}

\author{
H. Nagaraja*, R. Murali and H. Narayanaswamy
}

Department of Plant Pathology, College of Agriculture, Shivamogga, Karnataka, India

*Corresponding author

\section{A B S T R A C T}

\begin{tabular}{|l|}
\hline K e y w o r d s \\
Ralstonia solanacearum, \\
Inhibition zone, \\
Bioagents, Ginger \\
\hline Article Info \\
\hline Accepted: \\
02 May 2018 \\
Available Online: \\
10 June 2018 \\
\hline \hline
\end{tabular}

Keywords

\section{Introduction}

Ginger (Zingiber officinale Rosc) is an important commercial crop grown for its aromatic rhizomes, used both as spice and medicine. It is herbaceous tropical perennial plant belonging to the family Zingiberaceae. The rhizomes are white to yellowish brown in colour. It is usually grown as an annual crop.

The major constraint in the cultivation of ginger is because of rhizome rot disease and caused by the bacterium Ralstonia solanacearum E.F. Smith (Yabbuchi et al., 1995) is a devastating pathogen after the production of many economically important crops such as ginger, tomato, brinjal, chilli, tobacco, potato and banana (Kelman et al.,
Bacterial wilt caused by $R$. solanacearum is one of the most widely spread and destructive isease of ginger (Zingiber officinale Rosc.). An experiment on in vitro studies was carried out to find out the effectiveness of botanicals, bioagents and anti-bacterial chemicals to the growth of $R$. solanacearum. It was revealed from the evaluation that anong mean inhibition of $10.31 \mathrm{~mm}$ than other botanicin fluorescens (Shivamogga and Bangalore isolate) recorded maximum inhibition zone of $16.85 \mathrm{~mm}$ and $16.49 \mathrm{~mm}$ respectively, compared to Bacillus subtilis and Trichoderma harzianum. Whereas, results revealed from the evaluation of anti-bacterial chemicals viz., streptocycline + copper oxychloride showed maximum mean inhibition of $29.38 \mathrm{~mm}$ followed by streptocycline at $500 \mathrm{ppm}(27.07 \mathrm{~mm})$.

1994). The yield loss due to this disease in ginger ranged from 15 to 95 per cent (Javier, 1994).

$R$. solanacearum is a gram negative, rod shaped, strictly aerobic bacterium that is 0.5 $0.7 \times 1.5-2.0 \mu \mathrm{m}$ in size, with a single polar flagellum. Individual bacterial colonies are usually visible after 36 to $48 \mathrm{hrs}$ of growth at $28^{\circ} \mathrm{C}$ and colonies of ginger strains were highly fluidal with characteristic spiral pink centre whereas in the case of other strains fluidity and pink centre was less conspicuous (Kumar and Sarma, 2004; Sambasivam and Girija, 2006). Occasionally colonies of the mutant or non-virulent type appear uniformly round, smaller and butyrous or dry. Selective nutrient tetrazolium chloride (TZC) medium 
(Kelman, 1954) can differentiate the two colony types on this medium. Strains of $R$. solanacearum have been classified into five biovars (Kumar et al., 1993) and five races (Buddenhagen et al., 1962; Bin Li et al., 2010). The symptoms of bacterial rhizome rot of ginger are characterized by the appearance of water soaked patches or linear streaks on the collar region of the pseudo stem of ginger plants. These symptoms are followed by yellow or bronze coloration on margins of the lowermost leaves which gradually progress upwards, at later stages the leaves become flacid with intense yellow bronze colour and droop exhibiting typical wilt symptoms. Pseudostem can be easily separated from rhizome with a gentle pull (Dohroo, 1982).

The aim of present investigation was to study the effect of botanicals, bioagents and antibacterial chemicals on growth of $R$. solanacearum under in vitro conditions.

\section{Materials and Methods}

The experiment was designed to screen different commercially available chemicals for its antibacterial activity against $R$. solanacearum under in vitro using inhibition zone assay.

\section{Isolation and purification of $R$. solanacearum from bacterial rhizome rot affected ginger crop and soil}

The diseased plant and soil samples were collected from the farmer's field. The diseased plant samples were washed under tap water to remove the soil particle and air dried. The pseudostem of diseased plant of length 10 to $15 \mathrm{~cm}$ was first surface-disinfected with $70 \%$ ethanol for 2 minutes and $1 \%$ sodium hypochloride for 5 minutes followed by repeated washing in sterile water for 5 minutes to remove traces of sodium hypochloride. The surface sterilized bits were suspended in the five-milliliter sterile distilled water taken in test tube for ten minutes. After the water in test tube becomes turbid due to oozing of bacterial cells from cut ends of diseased tissue, the bacterial suspension was serially diluted in nine $\mathrm{ml}$ sterile water. One hundred microliter $(1 \mathrm{ml})$ of the bacterial suspension was poured onto the surface of solidified Triphenyl tetrazolium chloride agar (TZC) medium (Kelmen, 1954) containing (g/L) peptone 10; casein hydrolysate 1; glucose 5; agar 20; and distilled water 1L; pH 7.0 (1 \% TZC will added to a final concentration of $5 \mathrm{ml} / \mathrm{L}$ after autoclaving) using spread plate technique. A loopful of bacterial suspension was streaked into TZC medium and incubated at $28 \pm 2^{\circ} \mathrm{C}$ for 48 hours. To isolate the pathogen from soil, the soil samples were serially diluted and pathogen was isolated using TZC medium. At the end of incubation period, the plates were observed for the development of both the virulent and avirulent colonies of $R$. solanacearum. The virulent colonies were irregularly shaped, fluidal, dull white colonies with pink center, whereas, avirulent colonies small, round, convex, butyrous with large red pigment and white fluidal colonies without pink center described by Kelman (1954).

Evaluation of botanicals, bioagents and antibacterial chemicals

\section{Collection and preservation of botanicals}

The nine botanical species used in the present study viz., Onion (Allium cepa), Garlic (Allium sativum), Neem (Azadirachta indica), Turmeric (Curcuma longa L), Lantana (Lantana camara), Pongamia (Pongamia pinnata), Noni (Morinda citrifolia), Glyricidia (Gliricidia sepium) and Nilgiri (Eucalyptus obliqua) were collected locally. The plant leaves were collected from the fields around college campus shivamogga during November-2016. The leaves of all the tested plants were collected and washed in tap water 
and then in distilled water, $100 \mathrm{~g}$ of fresh sample was chopped and macerated in a surface sterilized pestle and mortar by adding $100 \mathrm{ml}$ of sterile water $(1: 1 \mathrm{w} / \mathrm{v})$. The extract was filtered through two layers of muslin cloth, filtrate thus obtained was used as a stock solution. To study the antibacterial mechanism of plant extracts at three different concentrations viz., 5 per cent, 10 per cent, 20 per cent was made by adding sterilized distilled water proportionately and stored in the refrigerator for the further use.

\section{Evaluation of bio agents}

Four bioagents viz., Trichoderma harzianum, T. viride, Pseudomonas fluorescens and Bacillus subtilis were evaluated for their efficacy against the growth of $R$. solanacearum by inhibition zone assay method. The cultures/formulations of these bioagents were obtained from department of Agricultural Microbiology, University of Agricultural and Horticultural Sciences, Shivamogga and Bangalore.

A heavy suspension of bacterial old culture $1 \times 10^{8} \mathrm{cfu} / \mathrm{ml}$ (3 day old) of $R$. solanacearum multiplied in nutrient broth $(20 \mathrm{ml})$ was mixed with lukewarm nutrient agar medium (1000 $\mathrm{ml})$ contained in Erlenmeyer's flask. Twenty $\mathrm{ml}$ of seeded medium was poured into the sterilized Petri plates and allowed to solidify.

A loopful culture of each of the antagonistic organism was placed in the centre of Petri plates containing the seeded medium. In case of fungal antagonists, mycelial discs of five $\mathrm{mm}$ (diameter) size taken from actively growing culture were placed in the centre of the plates. The inoculated plates were then incubated at $28^{0} \mathrm{C}$ for $48 \mathrm{~h}$. Observations were recorded for the zone of inhibition produced by antagonistic microorganisms around the growth of the pathogen.

\section{Evaluation of antibacterial chemicals}

Seven different chemicals viz., Kasugamycin, Streptocycline, Copper oxychloride, Copper hydroxide, Strptocycline + CoC, Plantomycin and Bleaching Powder were evaluated for their efficacy against the growth of $R$. solanacearum by inhibition zone assay. The chemicals were prepared at different concentrations. The bacterium was multiplied by inoculating the culture into the $20 \mathrm{ml}$ of nutrient broth taken in 'Erlenmeyer's' flask. The inoculated flasks were incubated at $28^{\circ} \mathrm{C}$ for $48 \mathrm{~h}$. The bacterial suspension was then seeded to the lukewarm nutrient agar medium $(1000 \mathrm{ml})$ and seeded medium was poured into the sterilized Petri plates and plates were allowed to solidify. The list of the chemicals as follows.

The filter paper discs (Whatman No. 42) measuring five $\mathrm{mm}$ in diameter were soaked in the respective chemical solution for 5 minutes and transferred onto the surface of the seeded medium in petri plates. Then plates were incubated at $280 \mathrm{C}$ for $48 \mathrm{~h}$ and observed for the production of inhibition zone around the filter paper discs. The results obtained were analysed statistically.

\section{Paper disc method}

The sterilized circular discs ( $5 \mathrm{~mm}$ dia.) of Whatman No. 44 were dipped in each of the concentration of a plant extract and test chemical for a few seconds. Likewise, the discs dipped in sterilized distilled water served as control. Three discs from each treatment were picked up and placed equidistantly in a Petri plate containing seeded 2, 3, 5-triphenyl tetrazolium chloride (TZC) medium. The three discs in a single Petri plate comprised three replications of each treatment. The Petri plates were then placed in the lower most shelf of a refrigerator $\left(\begin{array}{lll}5 & 0 & C\end{array}\right)$ for half an hour, thus allowing plant extracts and test chemicals to 
diffuse into the medium. The plates were then shifted to the incubator at $28 \pm 10 \mathrm{C}$. The inhibition zone $(\mathrm{mm})$ was measured with the help of a scale after 48 hours of incubation. The mean inhibition zone was worked out for each treatment and compared with the control.

\section{Results and Discussion}

Effect of nine plant leaf extract was evaluated against $R$. solanacearum by inhibition zone assay through paper disc method, as described in 'Material and methods'. The results are presented in the Table 1 and Plate 1. The results revealed that among the botanicals, neem leaf extract was found significantly superior than rest of the plant extract with mean inhibition zone of $10.31 \mathrm{~mm}$ followed by glyricidia $(7.19 \mathrm{~mm})$ and least inhibition zone was found in Turmeric $(0.31 \mathrm{~mm})$ respectively. The effect of botanicals on inhibition zone assay of $R$. solanacearum at 5 , 10,20 per cent concentrations differed significantly. Similar observations are made by (Raghu, 2011).

Study conducted on effect of bio agents on growth of $R$. solanacearum under in vitro by inhibition assay and the results were presented in Table 2 and Plate 2. Among the three bio agents, $P$. fluorescens (Shivamogga + Bangalore isolate) was found significantly superior in inhibiting the growth of pathogen (16.85 $\mathrm{mm}$ and $16.49 \mathrm{~mm}$ ) followed by Bacillus subtilis $(11.70 \mathrm{~mm})$. Whereas, among the fungal antagonists Trichoderma viride (Shivamogga isolate) recorded maximum inhibition zone of $8.08 \mathrm{~mm}$ followed by $T$. viride of Bengaluru isolate $(7.96 \mathrm{~mm}), T$. harzianum $(7.57 \mathrm{~mm})$ of Shivamogga isolate and T. harzianum (Bengaluru isolate) of 7.50 $\mathrm{mm}$ were on par With each other. The least inhibition zone of $2.50 \mathrm{~mm}$ formation was observed in Verticillium lecani. Bacterial bioagents such as $P$. fluorescens and $\mathrm{B}$. subtilis were significantly more effective compare to fungal bioagent, T. harzianum and $T$. viride against $R$. solanacearum. Literature supported for the in vitro evaluation, under biological control of plant diseases, various antagonistic organisms have been identified, which fight against the pathogens by different mechanisms viz., competition, lysis, antibiosis, siderophore production and hyper parasitism (Vidyasekaran, 1999). Bioagents viz., $P$. fluorescens and $B$. subtilis were reported efficient antagonists against $R$. solanacearum earlier by many workers (Gupta and Razdan, 2013; Raghu et al., 2011 and Roop Singh, 2017).

\section{Evaluation of antibacterial chemicals}

\begin{tabular}{|c|c|c|c|}
\hline Sl. No. & Chemical Name & Trade Name & $\begin{array}{l}\text { Concentration } \\
\text { (ppm) }\end{array}$ \\
\hline 1. & Biomycin & Kasugamycin & $100,500,1000$ \\
\hline 2. & Streptocycline & $\begin{array}{l}\text { Streptomycin sulphate } 90 \%+ \\
\text { tetracycline hydroxide } 10 \%\end{array}$ & $300,400,500$ \\
\hline 3. & Blue copper/ blitox & Copper oxy chloride & $2000,3000,4000$ \\
\hline 4. & Kocide & Copper hydroxide & $100,500,1000$ \\
\hline 5. & Strptocycline + Blitox & $\begin{array}{l}\text { Streptomycin sulphate } 90 \%+ \\
\text { tetracycline hydroxide } 10 \%)+ \text { Copper } \\
\text { oxy chloride }\end{array}$ & $300,400,500$ \\
\hline 6. & Plantomycin & $\begin{array}{l}\text { Streptomycin sulphate } 9 \%+\text { tetracycline } \\
\text { hydroxide } 1 \%\end{array}$ & $300,400,500$ \\
\hline 7. & Bleaching Powder & $40 \%$ Chlorine & $1000,1500,2000$ \\
\hline
\end{tabular}


Table.1 In vitro evaluation of botanicals on the growth of Ralstonia solanacearum

\begin{tabular}{|c|c|c|c|c|c|c|c|}
\hline \multirow[t]{2}{*}{$\begin{array}{l}\text { Sl. } \\
\text { No. }\end{array}$} & \multirow[t]{2}{*}{ Name of the Botanical } & \multirow[t]{2}{*}{ Botanical Name } & \multirow[t]{2}{*}{$\begin{array}{l}\text { Part/s } \\
\text { used }\end{array}$} & \multicolumn{3}{|c|}{$\begin{array}{l}\text { Mean diameter of inhibition zone }(\mathrm{mm}) \text { at } \\
\text { different concentrations }\end{array}$} & \multirow[t]{2}{*}{ Mean } \\
\hline & & & & 5 & 10 & 20 & \\
\hline 1. & Onion & Allium сера & Bulb & $1.50(1.58)^{*}$ & $2.47(1.86)$ & $3.38(2.09)$ & 2.45 \\
\hline 2. & Garlic & Allium sativum & Bulb & $4.95(2.44)$ & $5.85(2.62)$ & $6.87(2.80)$ & 5.89 \\
\hline 3. & Neem & Azardictra indica & Leaves & $8.33(3.06)$ & $10.17(3.34)$ & $12.43(3.67)$ & 10.31 \\
\hline 4. & Turmeric & Curcuma longa $\mathrm{L}$ & Rhizome & $0.00(1)$ & $0.43(1.20)$ & $0.50(1.22)$ & 0.31 \\
\hline 5. & Lantana & Lantana camera & Leaves & $1.00(1.41)$ & $3.40(2.10)$ & $4.00(2.24)$ & 2.80 \\
\hline 6. & Pongamia & Pongamia pinnata & Leaves & $0.73(1.32)$ & $1.77(1.66)$ & $1.98(1.73)$ & 1.49 \\
\hline 7. & Noni & Morinda citrifolia & Leaves & $0.83(1.35)$ & $1.70(1.64)$ & $1.83(1.68)$ & 1.46 \\
\hline 8. & Glyricidia & Gliricidia sepium & Leaves & $6.43(2.73)$ & $7.13(2.85)$ & $8.00(3.00)$ & 7.19 \\
\hline 9. & Nilgiri & Eucalyptus obliqua & Leaves & $0.50(1.22)$ & $1.67(1.63)$ & $1.90(1.70)$ & 1.36 \\
\hline 10. & Control & & & $0(1)$ & $0(1)$ & $0(1)$ & \\
\hline \multicolumn{4}{|c|}{ Factors } & S.Em \pm & CD at $1 \%$ & & \\
\hline \multicolumn{4}{|c|}{ Botanicals } & 0.09 & 0.24 & & \\
\hline \multicolumn{4}{|c|}{ Concentration } & 0.03 & 0.08 & & \\
\hline \multicolumn{4}{|c|}{ Interaction (B x C) } & 0.28 & 0.73 & & \\
\hline
\end{tabular}

* Figures in the parenthesis are $\sqrt{ } \mathrm{x}+1$ transformed values. 
Table.2 In vitro evaluation of bioagents against the growth of $R$. solanacearum

\begin{tabular}{|c|c|c|}
\hline SI No. & Bioagents & Inhibition zone (mm) \\
\hline 1 & Trichoderma harzianum (Shivamogga Isolate) & $7.57(2.93)^{*}$ \\
\hline 2 & T. harzianum (Bengaluru Isolate) & $7.50(2.84)$ \\
\hline 3 & T. viride (Shivamogga Isolate) & $8.08(3.01)$ \\
\hline 4 & T. viride (Bengaluru Isolate) & $7.96(2.99)$ \\
\hline 5 & Pseudomonas fluorescens (Shivamogga Isolate) & $16.85(4.22)$ \\
\hline 6 & P. fluorescens (Bengaluru Isolate) & $16.49(4.18)$ \\
\hline 7 & Verticillium lecanii & $2.50(1.87)$ \\
\hline 8 & Bacillus subtillis & $11.70(3.56)$ \\
\hline 9 & Control & 0.00 \\
\hline \multicolumn{2}{|r|}{ S.Em \pm} & 0.15 \\
\hline \multirow{2}{*}{\multicolumn{2}{|c|}{ CD at $1 \%$}} & 0.60 \\
\hline & & 2.58 \\
\hline
\end{tabular}

* Figures in the parenthesis are $\sqrt{ } \mathrm{x}+1$ transformed values.

Table.3 In vitro evaluation of antibacterial chemicals on the growth of $R$. solanacearum

\begin{tabular}{|c|c|c|}
\hline Treatment & Concentration (ppm) *** & Mean diameter of the inhibition (mm) \\
\hline \multirow{3}{*}{ Kasugamycin } & 100 & $6.05(2.66)^{*}$ \\
\hline & 500 & $6.17(2.68)$ \\
\hline & 1000 & $6.87(2.80)$ \\
\hline \multirow[t]{3}{*}{ Streptocycline } & 300 & $16.83(4.22)$ \\
\hline & 400 & $17.90(4.35)$ \\
\hline & 500 & $27.07(5.30)$ \\
\hline \multirow[t]{3}{*}{ Copper oxy chloride } & 2000 & $11.27(3.50)$ \\
\hline & 3000 & $11.80(3.58)$ \\
\hline & 4000 & $12.30(3.65)$ \\
\hline \multirow[t]{3}{*}{ Copper hydroxide } & 100 & $5.96(2.64)$ \\
\hline & 500 & $6.15(2.67)$ \\
\hline & 1000 & $6.45(2.70)$ \\
\hline \multirow[t]{3}{*}{ Strptocycline + COC } & $300+3000$ & $17.44(4.29)$ \\
\hline & $400+3000$ & $18.53(4.42)$ \\
\hline & $500+3000$ & $29.38(5.51)$ \\
\hline \multirow[t]{3}{*}{ Plantamycin } & 300 & $6.56(2.75)$ \\
\hline & 400 & $7.20(2.86)$ \\
\hline & 500 & $8.04(3.01)$ \\
\hline \multirow[t]{3}{*}{ Bleaching Powder } & 1000 & $1.22(1.49)$ \\
\hline & 1500 & $1.26(1.50)$ \\
\hline & 2000 & $1.30(1.52)$ \\
\hline \multirow[t]{4}{*}{ Control } & & 0.00 \\
\hline & S.Em \pm & 0.05 \\
\hline & CD at $1 \%$ & 0.19 \\
\hline & CV \% & 2.6 \\
\hline
\end{tabular}

* Figures in the parenthesis are $\sqrt{ } \mathrm{x}+1$ transformed values. 
Plate.1 In vitro evaluation of botanicals on the growth of $R$. solanacearum
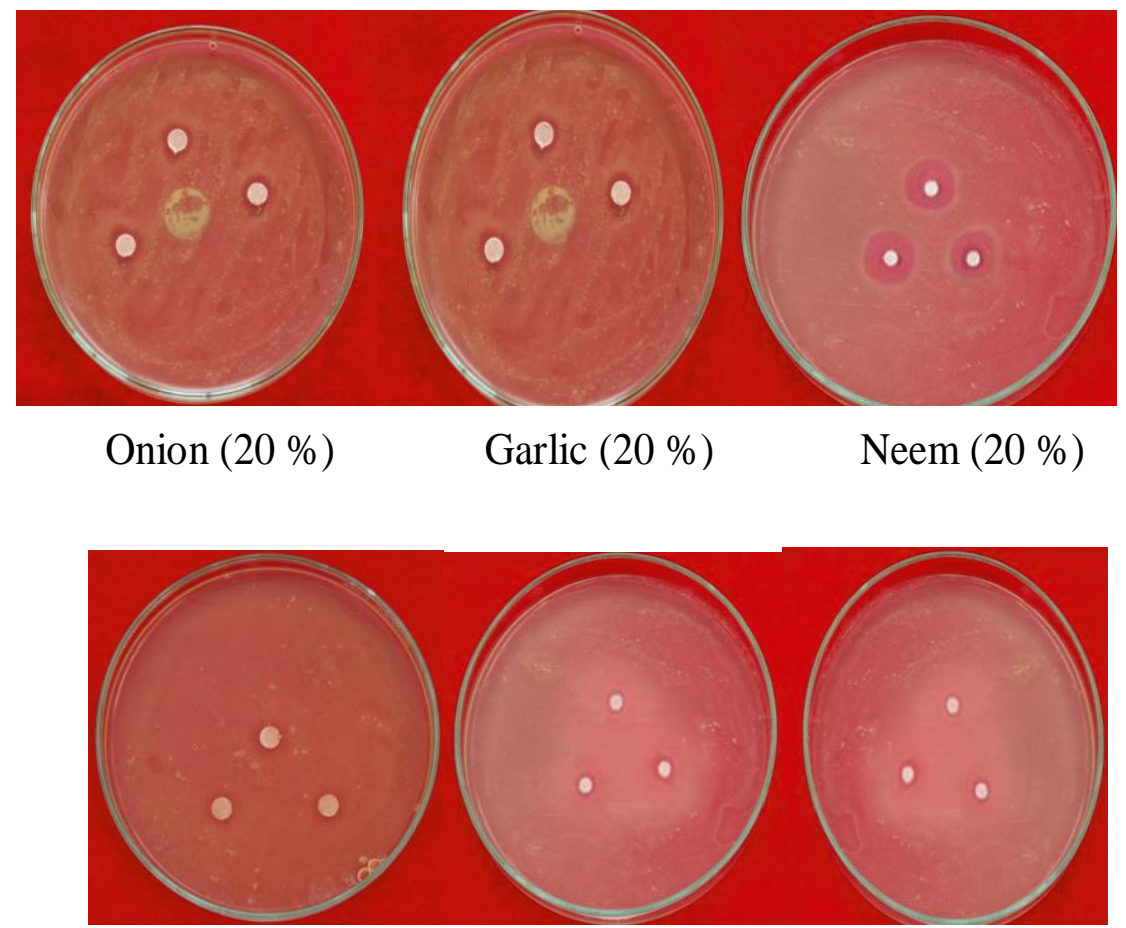

Turmeric (20\%) Lantana (20\%) Pongamia (20\%)

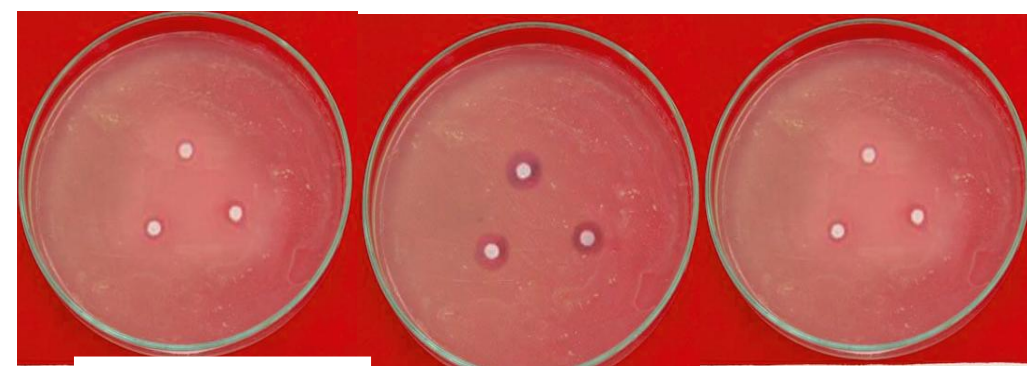

Noni $(20 \%) \quad$ Glyricidia $(20 \%) \quad$ Nilgiri $(20 \%)$

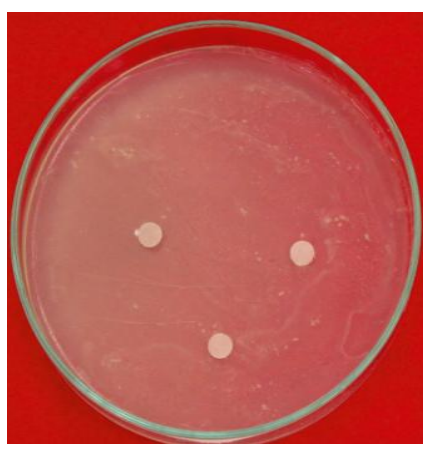

Control $(20 \%)$ 
Plate.2 In vitro evaluation of bioagents on the growth of $R$. solanacearum

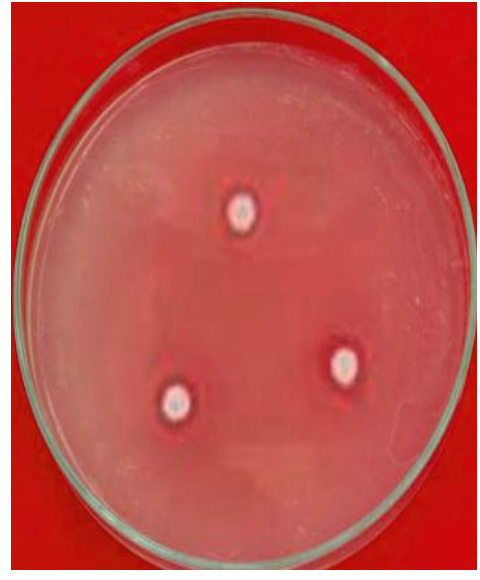

Trichoderma harzianum

(Shivamogga isolate)

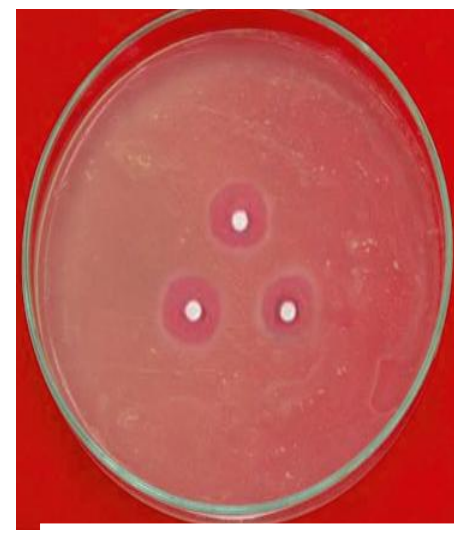

T. viridae

(Bangalore isolate)

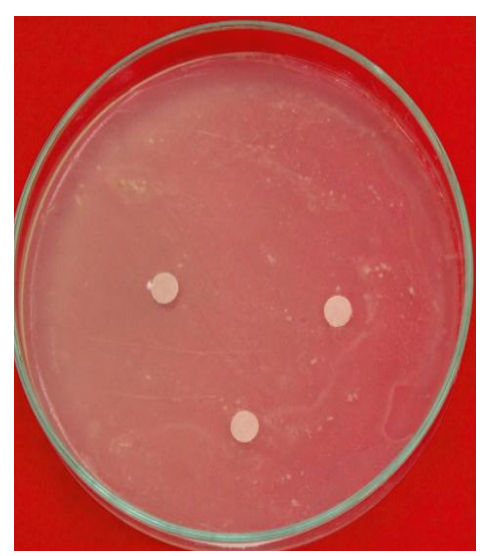

Verticillium lecani

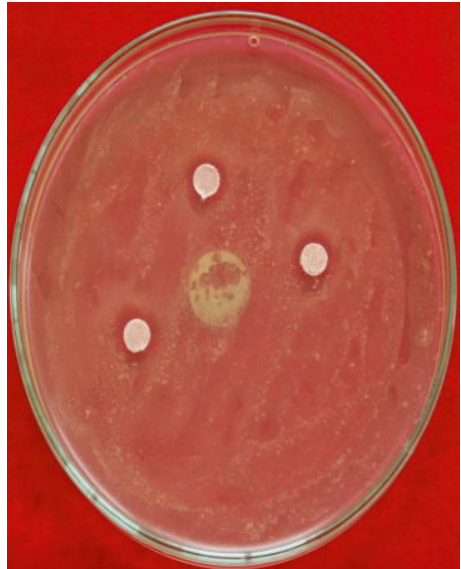

T. harzianum

(Bangalore isolate)

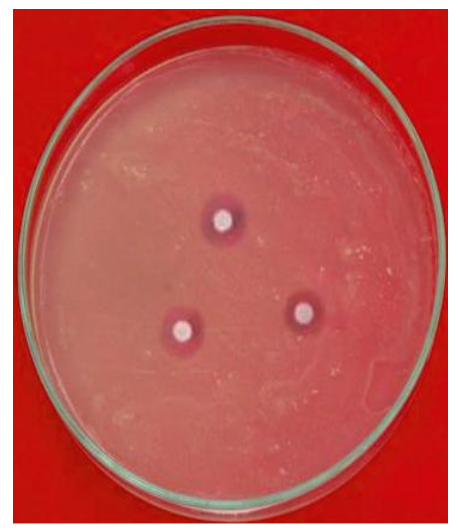

Pseudomonas fluorescens

(Shivamogga isolate)

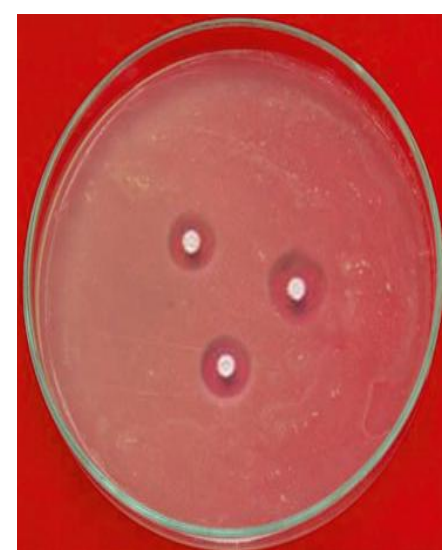

Bacillus subtillis

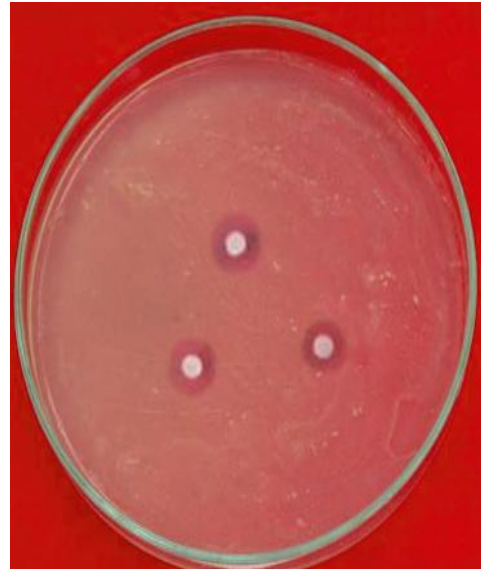

T. viridae

(Shivamogga isolate)

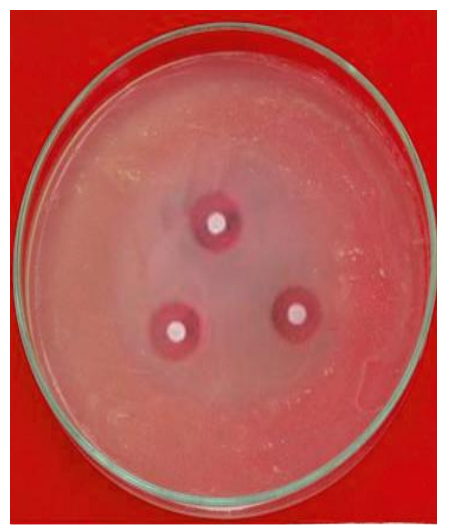

P. fluorescens

(Bangalore isolate)

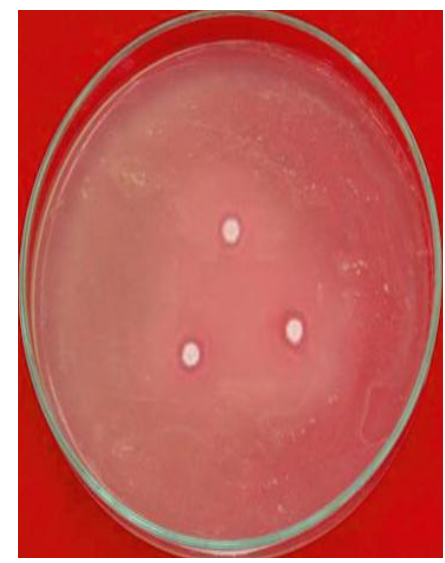

Control 
Plate.3 In vitro evaluation of antibacterial chemicals on the growth of $R$. solanacearum

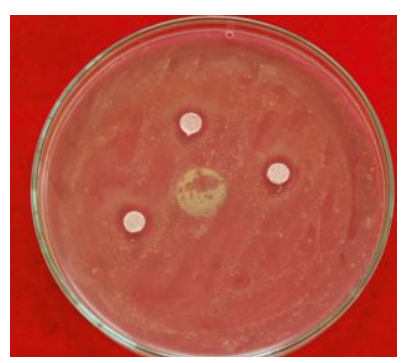

Kasugamysin (1000 ppm)

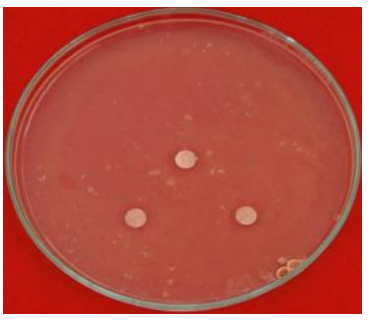

Copper hydroxide (1000 ppm)

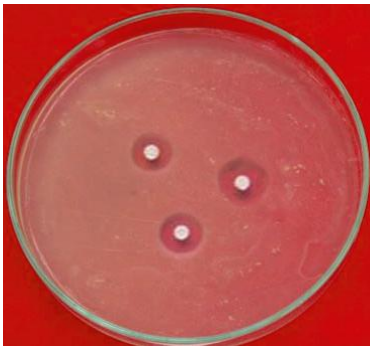

Streptocycline (500 ppm)

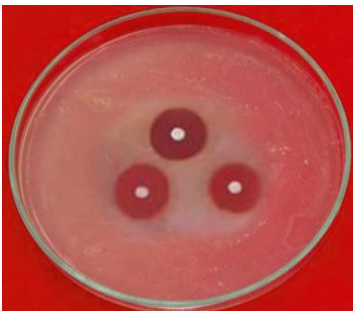

Streptocycline $(500 \mathrm{ppm})$ $+\mathrm{CoC}(3000 \mathrm{ppm})$

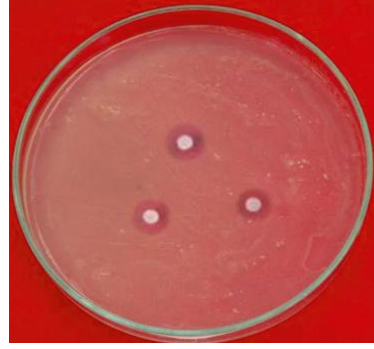

$\mathrm{CoC}(4000 \mathrm{p} p m)$

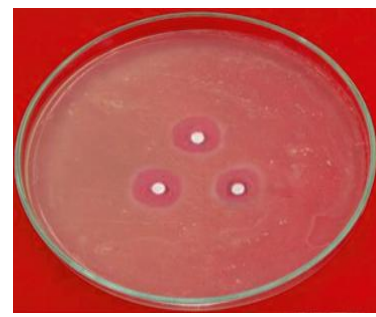

Plantomycine (500 ppm)

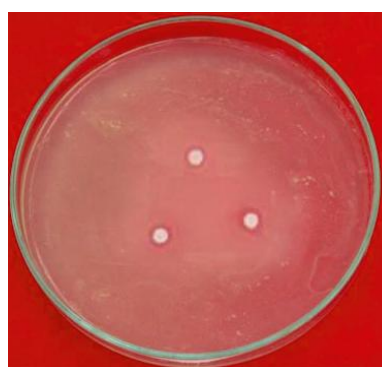

Bleaching powder (2000 ppm)
Data from the table revealed that, the efficacy of different bactericides; concentrations and their interaction on formation of inhibition zone differed significantly tabulate in Table 3 and Plate 3. Among different chemicals and their combinations, streptocycline + copper oxychloride at $500 \mathrm{ppm}+3000 \mathrm{ppm}$ showed the highest inhibition of $29.38 \mathrm{~mm}$ followed by Streptocycline $500 \mathrm{ppm}(27.07 \mathrm{~mm})$. However all other chemicals viz., kasugamycin, copper oxychloride, copper hydroxide and plantomycin were found effective and which remain on par with each

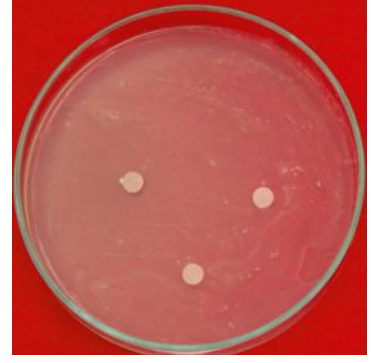

Control other. Whereas, bleaching powder was less effective even at higher concentrations. These results are in conformity with the findings of those reported earlier by several workers (Sunder et al., 2011; Gupta and Razdan, 2013; Owoseni and Sangoyomi, 2014, Raghu et al., 2011 and Roop Singh, 2017).

\section{References}

Bin Li, Ting Su, Rongrong Yu, Zhongyun Tao, Zhiyi Wu, Soad Algam A. E., Guanlin Xie, Yanli Wang and 
Guochang Sun. 2010. Inhibitory activity of Paenibacillus macerans and Paenibacillus polymyxa against Ralstonia Solanacearum. African J.Microbiol. Res., 4(19): 2048-2054.

Buddenhagen, I., Sequeria, L. and Kelman, A. 1962. Designation of races of Pseudomonas solanacearum. Phytopathol., 52: 72.

Dohroo, N. D., 1982, Further studies on Rhizome rot of ginger (Zingiber officinale Rosc.). Ph. D. Thesis, HPKVV, Solan, Himachal Pradesh (India).

Javier, I. Q., 1994, In: Bacterial wilt: G.L. Hartman and Hayward, A. C. (Eds), ACIAR Proceedings, Canberra, Austria. 1-159 pp.

Kelman, A. 1954. The relationship of pathogenicity in Pseudomonas solanacearum to colony appearance on a tetrazolium medium. Phytopathol., 44.

Kelman, A., Hartman, G. L. and Hayward, A. C., 1994, Bacterial wilt: the disease and its causative agent, Pseudomonas solanacearum. In: Hayward A.C., Hartman G.I. (Eds). Bacterial Wilt, CAB International, Oxon, UK. 1-7 pp.

Kumar, A. and Sarma, Y. R. 2004, Characterization of Ralstonia solanacearum causing bacterial wilt of ginger in India. Indian Phytopath., 57: 12-17.

Kumar, V., Singh, B.M. and Sugha, S.K. 1993. Variation in isolates of Pseudomonas solanacearum from Himachal Pradesh. Indian J. Mycol. Plant Pathol., 23: 232-236.
Owoseni, A.A. and Sangoyomi, T.E. 2014 Effect of solvent extracts of some plants on Ralstonia solanacearum. British Microbiol. Res. J., 4(1): 89-96.

Raghu, S., Ravikumar, M.R., Santosh Reddy M., Basamma, B.K. and Benagi, V. I. 2013. In vitro evaluation of antagonist micro-organisms against Ralstonia solanacearum. Ann. Pl. Protec. Sci., 21(1): 176-223.

Roop Singh and Jagtap, G.P., 2017. In Vitro Evaluation of Antibacterial Chemicals and Bioagents against Ralstonia solanacearum Infecting Bacterial Wilt in Ginger. Int.J.Curr.Microbiol.App.Sci (2017) 6(5): 2034-2045.

Sambasivam, P.K. and Girija, D. 2006. Biochemical characterization of Ralstonia solanacearum infecting Ginger. Ann. Pl. Protec. Sci., 14(2): 419-423.

Sunder, J., Jeyakumar, S., Kundu, A., Srivastava, R.C. and Kumar, D.A. 2011. Effect of Morinda citrifolia extracts on in-vitro growth of Ralstonia solanacearum. Arch. Appl. Sci. Res., 3(3): 394-402.

Yabuuchi, E., Kosako, Y., Yano, I. Hotta, H. and Nishiuchi, Y., 1995, Transfer of two Burkholderia and Alkanigens species to Ralstonia genus. Nov., Proposal of Ralstonia picketti (Ralston, Palleroni and Dougoroff, 1973). Comb. Nov. and Ralstonia eutropha (Davis, 1969) comb. Microbiology and Immunology, 39: 897-904.

\section{How to cite this article:}

Nagaraja, H., R. Murali and Narayanaswamy H. 2018. In vitro Evaluation of Botanicals, Bioagents and Antibacterial Chemicals against Rhizome Rot of Ginger Caused by Ralstonia solanacearum. Int.J.Curr.Microbiol.App.Sci. 7(06): 84-93. doi: https://doi.org/10.20546/ijcmas.2018.706.012 